\title{
Performance Measurement in Local Government: Institutional Factors
}

\author{
Rabina Laila \& Ermawati \\ Universitas Pembangunan Nasional Veteran Jakarta, Indonesia \\ ermawati@upnvj.ac.id
}

\begin{abstract}
The purpose of this research is to give empirical evidence of the impact of management commitment, resources, legislative mandate, management innovation, and reward/incentive on performance measurement. This research data was collected through a Google Form, in which 64 questionnaires were sent to the Head of the Planning Subdivision and their staff in each of the Regional Apparatus Organizations in the South Tangerang City Government. With the technique used, census sampling, this study took a quantitative approach employing non-probability sampling. Structural Equation Modeling (SEM) using PLS version 3.0 was used to evaluate the data. Management commitment and legislative mandate have a considerable impact on performance measurement. Meanwhile, resources, management innovation, and reward/incentive do not. This study has implications for local governments in terms of describing how performance measurement is carried out based on institutional factors, as well as making recommendations for improving local government performance measurements in the future to make them more reliable, effective, and efficient.
\end{abstract}

Keywords: Performance Measurement, Institutional Factors, Institutional Theory, Local Government.

\section{Introduction}

The implementation of good government governance (governance that is transparent, accountable, fair, effective, and efficient) is a real requirement for every government to realize the aspirations of the people in achieving the goals of the nation and state. We can see the government's efforts to improve the old government structure and achieve good governance in Law Number 32 of 2004 concerning Regional Government and Law Number 33 of 2004 concerning Financial Balance between the Central Government and Regional Governments. Both central and regional governments are competing to gain support from the community, one of which is by designing a performance measurement system as a form of accountability to the community. Performance measurement can be said to be a crucial tool for local governments, where it is not only to evaluate activities carried out by local governments but also can provide feedback and recommendations for government management processes in improving their performance in the future.

The Government Agency Performance Accountability Report (LAKIP), which is the ultimate outcome of the Government Agency Performance Accountability System (SAKIP), contains performance and results previously achieved on activities budgeted in the APBN/APBD in Indonesia's public sector. International research conducted by Sole and Schiuman (2010) also discusses the problem of performance measurement which finds that performance measurement only focuses on output $(31 \%)$, outcome $(21 \%)$ and efficiency (26\%). The findings of this study support those of Primarisanti and Akbar (2015), who found that performance measurement, still focuses on what has been done rather than on improvements that should be made. Jurnali and Nabiha (2015) revealed that the Indonesian government, even after years the performance evaluation system implemented in local governments still shows poor results. In Indonesia, the implementation of performance measurement has not yet been fully implemented. Reported from the belitungtimurkab.go.id website, namely the East Belitung Regency government website.

The State Administration Agency (LAN) assessed that there were still many weaknesses and shortcomings of the State Civil Apparatus (ASN) in compiling and making LAKIP. This is because many of the ASN s on duty do not understand the targets, and even often misjudge the LAKIP targets. Reports made by ASN also do not inform the success of agencies using performance measurement but rather report on the activities they have carried out and do not focus on the performance improvements they have made from the previous year (Primarisanti \& Akbar, 2015). According to the report of the Ministry of Administrative Reform and Reform of the Republic of Indonesia (Kemenpan), the evaluation of performance accountability in 2010 conducted on 29 provincial governments and 57 district/city governments, only 9 provinces and 5 districts/cities received the CC (Enough Good) predicate. This reflects that the accountability of local government performance in 2010 only reached $16.27 \%$ of the $20 \%$ target of local governments with predicate above CC (Enough Good). 
Table 1: Performance Evaluation of Province, Regency/City with Good Score

\begin{tabular}{llllll}
\hline Administrative Level & $\mathbf{2 0 1 5}$ & $\mathbf{2 0 1 6}$ & $\mathbf{2 0 1 7}$ & $\mathbf{2 0 1 8}$ & $\mathbf{2 0 1 9}$ \\
\hline Province & $50 \%$ & $65 \%$ & $85,92 \%$ & $94,12 \%$ & $97,06 \%$ \\
District/City & $2,38 \%$ & $14,53 \%$ & $35,40 \%$ & $46,85 \%$ & $57,28 \%$ \\
\hline
\end{tabular}

Source: Processed Data

Based on the performance evaluation of both the Province and the Regency/City from 2015-2019, it showed a significant increase. In 2019 the performance evaluation at the provincial level with the "good" category (CC or higher) increased from only $50 \%$ in 2015 to $97.06 \%$ in 2019. While the average score for the performance evaluation results in districts/cities with the "good" category (CC or higher) increased from only $2.38 \%$ in 2015 to 57.28 in 2019. Although there was an increase in performance evaluation every year, it was still found as much as 222 or $42.72 \%$ from districts/cities in Indonesia that still received an average performance evaluation score under the "good" category (CC or lower). Kemenpan still finds achievements that are below the target, especially in district/city governments due to several things, including 1) The commitment factor of leaders who are still lacking in preparing and implementing SAKIP; 2) Human resources who are responsible for the management of performance accountability have not been fully equipped with an understanding of good performance accountability so that if there is a change in the institution, either due to a change of leadership, mutation or promotion, it will disrupt ongoing performance; 3) The mindset that is not result-oriented and resistance to change. Given that there are still limitations in improving performance at the Regency/City Government level.

More attention is needed from the Central Government by providing direction and guidance to local government agencies to improve performance through performance measurement. Performance measurement is a method of evaluating the increase in work rhythm in order to achieve specific goals, such as information on the efficient use of resources in the production of goods and services, the quality of goods and services, and a comparison of the outcomes of activities for goals and the effectiveness of the actions taken to achieve them. Where performance measurement is formed from a rational/technocratic point of view, the adoption and implementation of performance measures is purely a technical matter, institutional factors are expected to describe the influence of the development and use of performance indicators on the public sector in Indonesia (Julnes \& Holzer, 2001). Institutional theory is an example of how to show that organizations are developed as a result of the institutional environment's pressure in the form of language and symbols that explain the organization's existence (DiMaggio \& Powell, 1983). So specifically, this research uses an isomorphism approach to explain the adoption and implementation of PMS. Aswar et al. (2020) also found that the 2012 performance evaluation of the provincial government received $75.75 \%$ with a CC predicate or good value. Meanwhile, in the same year, district/city governments only received $24.20 \%$ of good grades.

The provincial government has experienced a rapid improvement in terms of performance which previously in 2009 only received $3.7 \%$ which was considered good. On the other hand, district/city governments showed unsatisfactory results, only experiencing an increase of $1.16 \%$ in the period $2019-2012$. Based on the explanation above, this study aims to find out how local governments measure performance in their regions based on institutional factors consisting of management commitment, resources, legislative mandates, management innovation, and rewards/incentives. As a result, the goal of this research is to empirically demonstrate and investigate the impact of management commitment and resources on performance measurement, as well as to contribute to the literature by including legislative mandates, management innovation, and rewards/incentives as independent variables, as suggested by Aswar, Lovina and Ermawati (2020). In addition, the results of this study have several significant implications for local governments in Indonesia regarding organizational factors that affect the performance measurement system that can be used as recommendations for improving performance measurement to become more reliable, effective and efficient as recommendations for improving government performance in the coming period.

\section{Literature Review}

Performance Measurement: Performance measurement is the process of gathering, analyzing, and reporting data on the performance of individuals, organizations, institutions, systems, or the scope of their operations. The success of an organization can be measured by measuring its performance every year, the 
results of which can be used as input or evaluation for each organization to improve and improve the quality of the organization in the coming period (Aswar et al., 2020). Success in demonstrating and generating accountability to the public becomes legitimacy and direct support by the public. Mardiasmo (2004) suggests that performance measurement in the public sector is carried out to help improve government performance, is used for resource sharing and reference in making decisions in the public sector, and aims to realize accountability to the public and as an improvement in institutional communication. Performance measures are also influenced by the attitudes of superiors or employees in implementing the performance measurement program.

Utilization of performance information will be carried out well if the implementation of the program of performance measurement activities and personnel carrying out performance measurement feel that the performance information can improve organizational performance. Attitude as a measure of innovation is a pattern of basic assumptions found, made or developed by certain groups for organizational learning in solving existing problems (Julnes \& Holzer, 2001). Performance measurement will result in changes in the organization. These changes will be perceived differently by everyone in it (Sihaloho \& Halim, 2005). Primarisanti and Akbar (2015) state that the views and readiness of members to changes are caused by the innovations created and the consequences caused by the adoption of a performance measure. Walker et al. (2010) state that the influence of management innovation on organizational performance is fully influenced by performance measurement. However, Julnes and Holzer (2001) state that there is certainly a desire to encourage innovation from personnel or top management.

But the organization is not sure that the innovations made will bring influence and change to the performance measurement system at the Association of Government Finance Officials, City Management Association/ County International, and the National Association of College and University Business Officers in the United States. Good performance measurement indicators for organizations and individuals can be implemented based on rewards and punishments (Kloot, 1999). Every individual has an interest in improving their welfare; therefore incentives are a fundamental factor in improving and controlling their performance (Primarisanti \& Akbar, 2015). Khaeruddin and Aditya (2020) also stated that reward and punishment are factors that play a role in the performance measurement system, with these factors it is hoped that employees can be motivated and continuously improve their performance, but the Klaten District Education Office has not implemented a reward system and this we can conclude that not all local government organizations implement a reward system. Speklé and Verbeeten (2013) state that the use of an incentive-oriented PMS (performance measurement system) will negatively affect organizational performance.

Institutional Theory: This is a social theory that focuses on gaining sociological insight into an institution, how its members interact, and how their actions affect others around them (Scott, 1987). Institutional theory is formed due to the pressure of the institutional environment where each organization influences other forms of organization through the process of adoption or institutionalization (institutionalization). Isomorphism is a concept found in institutional theory (iso means the same and morph means form). DiMaggio and Powell (1983) state that isomorphism is like a "limiting process" which describes the homogenization of an organization in a given environment. Three mechanisms of isomorphism are identified by DiMaggio and Powell (1983), including 1) coercive isomorphism arises as a result of the influence of formal and informal pressure from other organizations and political forces in order to gain legitimacy for an organization. In institutional or institutional theory, coercive isomorphism will appear when the institution is required to adopt a similar way (i.e. PMS) in carrying out the provisions set out in the regulations.

These regulations are made and enforced by the central government about performance reporting and accountability. Thus, the source of isomorphic pressure in Indonesia is likely to come from regulations and laws implemented by the central government that affects government organizations, including local governments; 2) mimetic isomorphism, arises due to environmental uncertainty within the organization, which creates a tendency to imitate other organizations. The results of measuring and reporting their performance will also not be the same. Given the environmental uncertainty of an organization, superiors will direct their subordinates to imitate other organizations that have succeeded in achieving the same equality; 3) normative isomorphism, arising from the demands of professionalism through various channels as an effort to improve the quality of resources in each institution. If HR has a good education and has a lot of 
knowledge, the more likely the organization has similarities and equality with each other in management practices (DiMaggio \& Powell, 1983). The development of the hypothesis is motivated by factors that are expected to affect performance measurement. Therefore, the formulated hypothesis is as follows:

Hypothesis Development: The management commitment factor in institutional theory refers to normative isomorphism, which is demonstrated by the pressure on the organization to carry out the responsibilities that have been prescribed by each individual in order to fulfill the company's vision and goal. When institutions are in the same country, for example, Indonesia, but have different conditions in terms of area, population, human resources, total assets as well as financial and managerial capabilities. The nature of individual professionalism that arises with management commitment is also reflected in normative isomorphism (Primarisanti \& Akbar, 2015). The role of the leader is very important in improving the performance of the agency, as well as the commitment he gives to the organization, of course, being an example and self-motivation for employees to continue to improve their performance (Khaeruddin \& Aditya, 2020). According to Cavalluzo and Ittner (2004), top management commitment, decision-making power, and manager training have a positive and significant relationship with the development of performance measurement standards. Several studies were conducted by Cavalluzo and Ittner (2004), Primarisanti and Akbar (2015), Khaeruddin and Aditya (2020), Akbar et al. (2012), Gowon et al. (2018), and Nurkholis et al. (2010) proved that management commitment significantly affects performance measurement.

H1: Management commitment significantly affects performance measurement. In institutional theory, resources are derived from the pressure exerted by organizations that are obligated to give as many resources as possible to achieve their objectives. This is consistent with institutional theory connected to mimetic isomorphism, which states that pressure occurs as a result of coercion from other organizations that are able to provide appropriate resources for their organizations, causing other organizations to compete to equalize their abilities (Aswar et al., 2020). The resources in question, which include government staff, are all that can be employed to support work operations to meet targets. Because the effective and correct implementation of performance measures is dependent on the availability of adequate resources (Julnes \& Holzer, 2001), having adequate and consistent resources can be critical for performance measurement implementation. According to Aswar et al. (2020), resources have a substantial impact on performance assessment; the more resources available, the easier it is to measure performance. Resources have a substantial impact on performance measurement, according to Sihaloho \& Halim (2005) and Akbar et al. (2012).

H2: Resources significantly affect performance measurement. Organizations are required to comply with regulations that have been set by external parties, for example, the government, resulting in the emergence of coercive isomorphism from institutional theory which is present as pressure by institutions that have authority. Pressure in the form of regulation from the central government is still quite strong even though decentralization to local governments has been going on for more than a decade (Ahyaruddin \& Akbar, 2016). Gowon et al. (2018) state that the legislative mandate has a significant effect on performance measurement, because the regulations given by the central government cause local governments to have good accountability and have an impact on performance measurement, this research is also supported by Julnes and Holzer (2001). Cavalluzo and Ittner (2004) state that externally mandated PMS implementations are used to meet legal requirements. Sihaloho \& Halim (2005) also reveal that policies towards the adoption of a performance measure in government agencies are more influenced by mandates or provisions from outside the agency (e.g. government regulations, Presidential Instructions, and PERDA). The results by Ahyaruddin and Akbar (2016), Gowon et al. (2018), Julnes and Holzer (2001), Cavalluzo and Ittner (2004), and Akbar et al. (2012) concluded that the legislative mandate significantly affects performance measurement. Therefore, the hypothesis can be formulated as follows":

H3: The legislative mandate significantly affects performance measurement. In institutional theory, management innovation factors refer to normative isomorphism that arises from individual professionalism (Primarisanti \& Akbar, 2015). Management innovation can aid organizational change by facilitating external environment adaption and improving the efficiency and effectiveness of internal operations. Performance measurement will result in changes in the organization. Primarisanti and Akbar (2015) along with Sihaloho 
and Halim (2005) state that the views and readiness of personnel to changes caused by the innovations created and the consequences caused by adopting a performance measure.

H4: Management innovation significantly affects performance measurement. In institutional theory, the reward or incentive factor refers to normative isomorphism (Primarisanti \& Akbar, 2015). Individuals in both commercial and governmental organizations have a vested interest in increasing their own well-being, so incentives are a critical aspect in enhancing and controlling their performance (Indudewi \& Nafasita, 2012 in Primarisanti \& Akbar, 2015). According to Primarisanti and Akbar (2015), in the preparation of LAKIP at the SKPD of the Special Region of Yogyakarta, the pattern of incentives in the form of salary plus honorarium has a good influence on the establishment of a performance assessment system. Julnes and Holzer (2001) also show that required performance measurement works because it is backed up by monetary incentives.

H5: Rewards/Incentives significantly affect performance measurement.

\section{Methodology}

This research employs a causal research approach. To determine the impact of management commitment, resources, legislative mandate, management innovation, and rewards/incentives on performance measurement, the causal technique is utilized. Previous studies with a variety of different statements were used to measure this characteristic. The measurement of each variable is shown in Table 1.

Table 2: Variable Measurement

\begin{tabular}{|c|c|c|c|c|}
\hline Variable & Indicator & Scale & $\begin{array}{l}\text { No of } \\
\text { Statement }\end{array}$ & Sources \\
\hline $\begin{array}{l}\text { Performance } \\
\text { Measurement }\end{array}$ & $\begin{array}{l}\text { Collection, analysis, and reporting of } \\
\text { information related to the performance of } \\
\text { an institution, group, system, and elements }\end{array}$ & Likert & 7 & $\begin{array}{l}\text { Aswar, Lovina dan } \\
\text { Ermawati (2020) }\end{array}$ \\
\hline $\begin{array}{l}\text { Management } \\
\text { Commitment }\end{array}$ & $\begin{array}{lcr}\text { Management loyalty, management } \\
\text { engagement, responsibility and } \\
\text { management agreement }\end{array}$ & Likert & 3 & $\begin{array}{l}\text { Aswar, Lovina dan } \\
\text { Ermawati (2020) }\end{array}$ \\
\hline Resource & $\begin{array}{l}\text { Human resources, technology, information, } \\
\text { tangible assets or anything of value }\end{array}$ & Likert & 5 & $\begin{array}{l}\text { Aswar, Lovina dan } \\
\text { Ermawati (2020) }\end{array}$ \\
\hline $\begin{array}{l}\text { Legislative } \\
\text { Mandate }\end{array}$ & $\begin{array}{l}\text { Written or oral government regulations, } \\
\text { government decrees }\end{array}$ & Likert & 2 & $\begin{array}{l}\text { Akbar, Pilcher dan } \\
\text { Perrin (2012) }\end{array}$ \\
\hline $\begin{array}{l}\text { Management } \\
\text { Innovation }\end{array}$ & $\begin{array}{l}\text { Novelty and change, management ideas in the } \\
\text { form of new products or services, technology } \\
\text { for new production processes, new structural } \\
\text { and administrative systems or new plans for } \\
\text { organizational members }\end{array}$ & Likert & 4 & $\begin{array}{l}\text { Primarisanti dan } \\
\text { Akbar (2015) }\end{array}$ \\
\hline $\begin{array}{l}\text { Reward } \\
\text { /Incentive }\end{array}$ & $\begin{array}{l}\text { Rewards or service rewards in the form of } \\
\text { physical or non-physical }\end{array}$ & Likert & 2 & $\begin{array}{l}\text { Primarisanti dan } \\
\text { Akbar (2015) }\end{array}$ \\
\hline
\end{tabular}

Source: Produced by researchers

The sample used is closely related to the performance measurement produced by regional organizations that understand the topic being raised and are able to provide the necessary information. The sample was selected using non-probability sampling with a saturated sampling technique (census) to each Head of the Planning Subdivision and their staff at the Regional Apparatus Organization in the South Tangerang City Government, and the number of respondents obtained was 64 people. The Indonesian city government is used as an example to demonstrate the broader challenges with performance measurement at the local government level. Table 3 provides a list of structural positions. 
Table 3: List of South Tangerang City Regional Apparatus Organizations

\begin{tabular}{ll}
\hline Regional Apparatus Organization & Number of Local Government \\
\hline Inspectorate & 2 \\
Regional Secretariat & 1 \\
Regional Committee & 12 \\
Civil Service Unit & 2 \\
Local Agent & 33 \\
Districts & 14 \\
Number of Subdivision Heads and Employees & 64 \\
\hline
\end{tabular}

Source: Self Calculation

A questionnaire-based on indicators from prior studies was utilized to collect data for this investigation. The questionnaires were delivered to the South Tangerang City Government's 38 Regional Apparatus Organizations. The questionnaire was delivered electronically to one of the general and personnel department workers in each Regional Apparatus Organization by WhatsApp or e-mail in a Google form link that was generated for distribution to the Head of the Planning Subdivision.

\section{Results}

The sample of this research is the Head of the Planning Subdivision and his staff in 38 South Tangerang City Government Regional Apparatus Organizations that meet the criteria. General department officials and personnel from each Regional Apparatus Organization aided in the distribution of the surveys. This study's data collection process took 40 days and yielded 64 replies, with an 84.2 percent response rate.

Table 4: Descriptive Statistics

\begin{tabular}{lll}
\hline Variables & Mean & Std. Dev. \\
\hline Performance Measurement (PM) & 4,21 & 0,088 \\
Management Commitment (MC) & 3,88 & 0,455 \\
Resources (RS) & 4,28 & 0,099 \\
Legislative Mandate (LM) & 4,24 & 0,569 \\
Management Innovation (MI) & 4,16 & 0,125 \\
Reward/Incentive (R) & 3,59 & 0,033 \\
\hline
\end{tabular}

Source: Self Calculation

The results of descriptive statistics in Table 4 show the overall results of descriptive statistical analysis; the magnitude of the standard deviation is smaller than the magnitude of the mean value. The smaller the resulting standard deviation, it illustrates that there is a fairly high homogeneity in the processed data.

Table 5: Convergent Validity and Reliability

\begin{tabular}{llll}
\hline Variables & Ave & Composite Reliability & Cronbach Alpha \\
\hline PM & 0,699 & 0,942 & 0,928 \\
MC & 0,630 & 0,836 & 0,731 \\
RS & 0,620 & 0,888 & 0,843 \\
LM & 0,812 & 0,896 & 0,779 \\
MI & 0,681 & 0,895 & 0,862 \\
R & 0,957 & 0,978 & 0,956 \\
\hline
\end{tabular}

Source: Self Calculation

The convergent validity was tested using the Average Variance Extracted (AVE) method. The AVE value that should be used is more than 0.50. (Hair et al., 2014). Table 5 shows that all AVE values in each variable are greater than 0.50 , based on the test findings. These results illustrate that the variables in this study are valid. In addition, the value of composite reliability and the value of Cronbach's Alpha can be said to be reliable or reliable if the value is equal to or greater than 0.7 (Garson, 2016). Each construction has a score of more than 
0.70 for the second value. These findings show that all of the structures met the requirements for high reliability.

Table 6: Fornell-Larcker Criteria for Discriminant Validity

\begin{tabular}{lllllll}
\hline & $\begin{array}{l}\text { Management } \\
\text { Commitment } \\
\text { (PM) }\end{array}$ & $\begin{array}{l}\text { Resources } \\
\text { (RS) }\end{array}$ & $\begin{array}{l}\text { Legislative } \\
\text { Mandate } \\
\text { (MI) }\end{array}$ & $\begin{array}{l}\text { Management } \\
\text { Innovation } \\
\text { (MOT) }\end{array}$ & $\begin{array}{l}\text { Reward } \\
\text { (R) }\end{array}$ & $\begin{array}{l}\text { Performance } \\
\text { Measurement } \\
\text { (PM) }\end{array}$ \\
\hline MC & 0,794 & & & & & \\
RS & 0,637 & 0,787 & & & & \\
LM & 0,389 & 0,484 & 0,901 & & & \\
MI & 0,642 & 0,691 & 0,390 & 0,825 & 0,978 & \\
R & 0,145 & 0,310 & 0,139 & 0,425 & 0,174 & 0,836 \\
PM & 0,590 & 0,574 & 0,475 & 0,505 & 0 \\
\hline
\end{tabular}

The discriminant validity test was also performed using the Fornell-Larcker Criteria (Table 6). Each variable with a construction value greater than 0.70 is considered to be legitimate if it has a value greater than 0.7. (Hair et al., 2014). Performance measurement (PM) has a value of 0.836 . Management commitment has a value of 0.794 . Resources have a value of 0.787 . The Legislative Mandate has a value of 0.901 . Management Innovation has a value of 0.825 . The value of the reward is 0.978 . As a result, all constructs for each variable can be inferred to be valid.

Table 7: PLS Path Algorithm and Bootstrapping

\begin{tabular}{llll}
\hline & Path Coefficient & T-Value & P-Value \\
\hline MC $\rightarrow$ PM & 0,330 & 2,787 & 0,006 \\
RS $\rightarrow$ PM & 0,220 & 1,408 & 0,160 \\
LM $\rightarrow$ PM & 0,219 & 2,118 & 0,035 \\
MI $\rightarrow$ PM & 0,054 & 0,359 & 0,720 \\
R $\rightarrow$ PM & 0,005 & 0,053 & 0,958 \\
\hline
\end{tabular}

Meanwhile, the route coefficient value to examine the association between management commitment (MC) and PM performance measurement is 0.330 , as shown in Table 7 , resource (RS) is 0.220 performance measurement (PM), and mandate is 0.220 . legislative (LM) with performance measurement (PM) which is worth 0.219 , management innovation (MI) with performance measurement (PM) which is worth 0.054 , Last is the relationship between reward/incentive (R) on performance measurement (PM) which is worth 0.005 . Table 7 also shows the outcomes of hypothesis testing utilizing SEM with SmartPLS version 3.0, specifically the PLS route method and bootstrapping. The results show that the management commitment $(\mathrm{MC},=2.787$ and $\mathrm{P}=0.006)$ and the legislative mandate $(\mathrm{LM},=2.118$ and $\mathrm{P}=0.035)$ affect the performance measurement, which means that $\mathrm{H} 1$ and $\mathrm{H} 3$ are accepted. Meanwhile, the resources $(\mathrm{RS},=0.408$ and $\mathrm{P}=0.160$ ), management innovation $(\mathrm{MI},=0.359$ and $\mathrm{P}=0.720)$, Rewards/incentives did not have a significant relationship on performance measurement $(R=0.053$ and $\mathrm{P}=0.958)$, indicating that $\mathrm{H} 2, \mathrm{H} 4$, and $\mathrm{H} 5$ are rejected.

\section{Discussion}

According to the findings, managerial commitment has a considerable impact on performance measurement. This is due to management or the Head of the Planning Subdivision's commitment to be able to influence employees' work and be accountable for the results and data used in decision-making. The findings of this study corroborate those of Akbar et al. (2012), who performed on senior regional government finance executives across Indonesia, Gowon et al. (2018) conducted in SKPD in Central Java, Cavalluzo and Ittner (2004) conducted on civil managers of executive institutions in the United States General Accounting Office, Nurkholis et al. (2010) which was conducted in SKPD in East Java. The four studies state that successful change in an organization depends on employee participation along with direction and commitment from management. These results support the institutional theory, especially the notion of normative isomorphism which explains that the State Civil Apparatus (ASN), the regional apparatus organization where he works puts pressure on the Head of the Planning Subsection and his team to complete the responsibilities that have been 
assigned to each employee in order to fulfill the organization's vision and objective. Then also the professionalism that is owned by the management, namely the Head of the Planning Subdivision, causes the commitment he gives can have a good impact on the continuity of the organization where he works. Empirical evidence shows that resources do not significantly affect performance measurement. This is because the resources in each OPD in the South Tangerang City Government are not yet fully available.

This is illustrated by the results of the descriptive statistical test which explains that as many as 27 respondents or equivalent to $42 \%$ of 64 respondents answered neutrally so that the resource variable has not become a strong factor in improving performance measurement in each OPD in the South Tangerang City Government. The findings of this study contradict with Julnes and Holzer (2001) at the Association of Government Finance Officers, International City/District Management Association, and National Association of College Business Officers in the United States, as well as Sihaloho and Halim (2005) on government employees in the province of the Special Region of Yogyakarta. However, the findings of this study are consistent with Khaeruddin and Aditya (2020), which claims that resources have no significant impact on performance measurement because the Klaten District Education Office faces several problems related to its human resources, including poor implementation, weak due to a lack of resources, and poor implementation due to a lack of resources. These results do not support the institutional theory, especially the idea of mimetic isomorphism which explains that environmental uncertainty, especially in terms of human resources owned by Regional Apparatus Organizations (OPD) in the South Tangerang City Government is still high and the tendency to imitate other City Governments that have established better performance measures is still not maximized. The results show that the legislative mandate significantly affects performance measurement. This is because the mandate given by the central government to each Regional Apparatus Organization in South Tangerang City is still dominant and causes performance measurement to be in line with the mandate of the legislature.

With the regulations given by the central government, causing local governments to have good accountability and impact on performance measurement. Julnes and Holzer (2001) conducted research at the Association of Government Finance Officers, the International City/County Management Association, and the National Association of College Business Officers in the United States, which found a significant relationship between legislative mandates and performance measurement. Then also supported by Akbar et al. (2012), Gowon et al. (2018), Ahyaruddin and Akbar (2016), and Sihaloho and Halim (2005). Furthermore, in a study in the US government to apply multidimensional performance measurement for accountability purposes, Cavalluzo and Ittner (2004) stated that the implementation of an externally mandated performance measurement system (PMS) was used to meet legal requirements. These results support the institutional theory, especially the idea of coercive isomorphism which explains that ASN, especially the Head of the Planning Subdivision and their staff in the South Tangerang City Government are required to comply with and carry out the tasks that have been given in accordance with the mandate of the central government, which has an impact on the results of performance measurement and reporting through LAKIP in their local government. Meanwhile, empirical research indicates that management innovation has little impact on performance measurement.

This shows that the innovation provided by the Head of the Planning Subdivision in each OPD in the South Tangerang City Government has not been fully found, this is evidenced by statistical tests which illustrate that as many as 28 respondents or equivalent to $43 \%$ of 64 respondents answered neutrally. So that the innovation provided by the Head of the Planning Subdivision has not become a strong factor in improving performance measurement for each OPD in the South Tangerang City Government. The results of this study are in line with Julnes and Holzer (2001) which states that the desire to encourage innovation from every member, employee or top management is certainly there, but the organization is not sure that the innovations carried out will bring influence and change to the system. While the results of this study contradict with Sihaloho and Halim (2005), Primarisanti and Akbar (2015), and Walker et al. (2010) which states that management innovation affects performance measurement because of the views and readiness of members to changes caused by the innovations created and the consequences caused by the adoption of a performance measure. The results of this study are not supported by institutional theory, especially the notion of normative isomorphism which explains that the change from the existence of management innovations carried out by the ASN or the Head of the Planning Subdivision as demand for professionalism has not fully run optimally. 
Finally, empirical evidence shows that rewards/incentives do not significantly affect performance, measurement. This illustrates that the reward system given to the Head of the Planning Subdivision and his staff is not the main motivation to improve performance measurement in the South Tangerang City Government. Then for an ASN, doing a good job in his division is a form of community service, so to measure good performance and prepare an appropriate LAKIP is merely a form of service to the community and the area where he works. In addition, the results of the descriptive statistical test showed that $54.7 \%$ of respondents were neutral on the two statements related to the reward system at their institution, which indicates that the reward system in each OPD has not been fully implemented in measuring performance and preparing LAKIP. This result is in line with the study conducted by Khaeruddin and Aditya (2020) at the Klaten District Education Office. Based on this, this research is not supported by institutional theory, especially the notion of normative isomorphism which explains that ASN, especially the Head of the Planning Subdivision and their staff in measuring performance does not rely on awards/incentives given, but rather a form of dedication to the area where they work and the community.

\section{Conclusion}

The South Tangerang City Government underwent several tests connected to performance measurement that was influenced by management commitment, resources, legal mandates, management innovation, and awards/incentives. The following conclusion was reached: Management commitment has a significant influence on performance measurement, which means that if the Head of the Planning Subdivision has a high level of commitment and provides the right direction so that it can influence employees at work and is responsible for the results and use of data in decision making, the easier it is to measure performance. Resources have no substantial impact on performance measurement, implying that the more resources an institution has; the more difficult it is to assess performance. The legislative mandate has a considerable impact on performance assessment, meaning that the easier it is to monitor performance, the higher the legislative mandate granted by the central government.

Management innovation has no effect on performance measurement, implying that the lower the level of management innovation that delivers improvements to an agency, the less convenient it is to measure performance. Finally, rewards and incentives do not affect performance assessment, which means that the lesser the reward or incentive system given to the Head of the Planning Subdivision and his employees, the more difficult it is to quantify performance. Then, for the results to be more valid and in-depth, more research is needed to increase the object and sample of research respondents. Suggestions that can be given to the Head of the Planning Subdivision, especially in the South Tangerang City Government, are expected to be able to place their staff in positions that are in accordance with their abilities, allowing each Regional Apparatus Organization's ability in human resources to run optimally. Then, the Head of the Planning Subdivision is expected to be able to provide innovations that bring changes to performance measurement so that they are able to align the quality of their regions with other regions that are better.

\section{References}

Ahyaruddin, M. \& Akbar, R. (2016). The relationship between the use of a performance measurement system, organizational factors, accountability, and the performance of public sector organizations. Journal of Indonesian Economy and Business, 31(1), 1. https://doi.org/10.22146/jieb.10317.

Akbar, R., Pilcher, R. \& Perrin, B. (2012). Performance measurement in Indonesia: the case of local government. Pacific Accounting Review, 24(3), 262-291. https://doi.org/10.1108/01140581211283878.

Aswar, K., Lovina \& Ermawati. (2020). The effect of organizational factors on performance measurement in Indonesia local governments. International Journal of Economics and Business Administration, 8(4), 122-131. https://doi.org/10.35808/ijeba/574.

Belitungtimurkab.go.id. (2017). Banyak ASN Belum Mampu Susun LAKIP Dengan Baik. Dari: https://www.belitungtimurkab.go.id/?p=6743 (Diakses 22 Maret 2021).

Berita Universitas Gajah Mada Fakultas Ekonomi dan Bisnis. (2019). Sudah Hampir 20 Tahun Sistem Pengukuran Kinerja Diimplementasikan di Indonesia, Tapi Kenapa Kinerjanya Masih Rendah? Dari: https://fe.ugm.ac.id/id/berita/2664-sudah-hampir-20-tahun-sistem-pengukuran-kinerja- 
diimplementasikan-di-indonesia-tapi-kenapa-kinerjanya-masih-rendah (Diakses 22 Maret 2021).

Cavalluzzo, K. S. \& Ittner, C. D. (2004). Implementing performance measurement innovations: Evidence from the government. Accounting, Organizations and Society, 29(3-4), 243-267. https://doi.org/10.1016/S0361-3682 (03)00013-8.

De Lancer Julnes, P. \& Holzer, M. (2001). Promoting the utilization of performance measures in public organizations: An empirical study of factors affecting adoption and implementation. Public Administration Review, 61(6), 693-708. https://doi.org/10.1111/0033-3352.00140.

DiMaggio, P. J. \& Powell, W. W. (1983). The iron cage revisited: institutional isomorphism and collective rationality in organizational fields. American Sociological Review, 48(2), 147-160. https://doi.org/10.2307/2095101.

Gowon, M., Rohman, A., Basuki, P. \& Fortunasari. (2018). The effect of performance measurement system implementation on the local government performance. International Journal of Civil Engineering and Technology, 9(1), 149-164.

Hair, J. F., Sarstedt, M., Hopkins, L. \& Kuppelwieser, V. G. (2014). Partial least squares structural equation modeling (PLS-SEM): An emerging tool in business research. European Business Review, 26(2), 106121. https://doi.org/https://doi.org/10.1108/EBR-10-2013-0128.

Jurnali, Teddy. \& Nabiha, Siti, A. (2015). Performance management system for local government: the Indonesian experience. Global Business Review, 16(3), 351-363. https://doi.org/10.1177/0972150915569923.

Kementerian Pendayagunaan Aparatur Negara dan Reformasi Birokrasi. (2011). Seluruh Pemda Harus Memiliki Indikator Kinerja Utama (IKU). Dari: https://menpan.go.id/site/berita-terkini/seluruhpemda-harus-miliki-indikator-kinerja-utama-iku (Diakses 22 Maret 2021),

Khaeruddin, F. A. R. (2020). Evaluasi implementasi sistem akuntabilitas kinerja instansi pemerintah daerah kabupaten/kota. $\quad$ ASSETS, $10(2), \quad$ 195-209. alauddin.ac.id/index.php/assets/article/view/18602.

Kloot, L. (1999). Performance measurement and accountability in Victorian local government. The International Journal of Public Sector Management, 12(7), 565-583.

Mardiasmo, M. (2004). Akuntansi Sektor Publik. Yogyakarta: Andi.

Nurkholis, N., Mohamad, M. H. S. \& Ismail, S. (2010). Antecedents to performance, measurement under results-based management: the case of local government agencies in East Java, Indonesia. International Public Management Network Conference 2010, April 2014. http://irep.iium.edu.my/7780/.

Primarisanti, H. \& Akbar, R. (2015). Factors influencing the success of performance measurement: evidence from local government. Journal of Indonesian Economy and Business, 30(1), 56. https://doi.org/10.22146/jieb.7334.

Sihaloho, F. L. \& Halim, A. (2005). Pengaruh faktor-faktor rasional, politik, dan kultur organisasi terhadap pemanfaatan informasi kinerja instansi pemerintah daerah. Simposium Nasional Akuntansi, 8, 15-16. https://smartaccounting.files.wordpress.com/2011/03/kasppa-02.pdf.

Sole, F. \& Schiuma, G. (2010). Using performance measures in public organizations: Challenges of Italian public administrations. Measuring Business Excellence, 14(3), 7084.https://www.researchgate.net/publication/235251791_Using_performance_measures_in_public_ organisations_Challenges_of_Italian_public_administrations.

Speklé, R. F. \& Verbeeten, F. H. M. (2013). The use of performance measurement systems in the public sector: Effects on performance. Management Accounting Research, 25(2), 131-146. https://doi.org/10.1016/j.mar.2013.07.004.

Walker, R. M., Damanpour, F. \& Devece, C. A. (2010). Management innovation and organizational performance: The mediating effect of performance management. Journal of Public Administration Research and Theory, 21(2), 367-386. https://doi.org/10.1093/jopart/muq043. 